$$
\begin{aligned}
& \text { 報文 } \\
& \text { ナトリウム㠌取量の推定方法に関する検討 } \\
& \begin{array}{c}
\text { 永山育 子*1, 大 里 進 子*2, 大 関 静 枝*3 } \\
\text { 高 良 治 江*4, 松 田 民 子*5, 安 武 律*6 } \\
\end{array} \\
& \text { *3 元: 中村学園大学食物栄養科, *4 香蘭女子短期大学家政科 } \\
& { }^{* 5} \text { 精華女子短期大学家政科, }{ }^{* 6} \text { 熊本女子大学生活科学部 } \\
& \text { *7 鹿児島純心女子短期大学家政科 }
\end{aligned}
$$

\title{
A Check on the Accuracy of Methods in Estimating Sodium Intake
}

\author{
Ikuko NAGAYAMA,*1 Shinko ŌSATO,*2 Shizue ŌZEKI,*8 \\ Harue KŌRA,*^ Tamiko MATSUDA,*5 Ritsu YASUTAKE*6 \\ and Nobuko WAKAHARA*7 \\ *1 Department of Domestic Science, Tottori Women's Junior College, Kurayoshi, 682 \\ *2 Department of Food and Nutrition, Higashichikushi Junior College, Kitakyūshū, 803 \\ *3 Department of Food and Nutrition, Nakamura Gakuen College, Fukuoka, 814 \\ *4Department of Domestic Science, Köran Women's Junior College, Fukuoka, 815 \\ *5 Department of Domestic Science, Seika Women's Junior College, Fukuoka, 816 \\ *6 Department of Domestic Science, Kumamoto Women's University, Kumamoto, 862 \\ ${ }^{* 7}$ Department of Domestic Science, Kagoshima Junshin Women's Junior College, Kagoshima, 890
}

Nippon Eiyō Shokuryō Gakkaishi (J. Jpn. Soc. Nutr. Food Sci.) 39, 89 93 (1986)

A questionnaire survey on sodium intake was made in 33 female professional nutritionists. The answers to the questions were coded according to a numerical system of rating and the scores of each question were totaled individually (sodium intake score). Concurrently with the questionnaire, sodium content of meals consumed by the same subjects during a 3-day experimental period were determined by two methods: chemical analysis (analyzed value), and calculation using the Japanese Standard Food Composition Table : Supplement to the 3rd edition (calculated value). Twenty four-hour urine of the subjects during this period were also analyzed chemically (urinary sodium value).

Analyzed, calculated and urinary sodium values were compared with each other and relationships between sodium intake scores and these three values were studied.

The results obtained were as follows :

1) The means of calculated, urinary sodium and analyzed values were $3,806 \pm 753 \mathrm{mg}, 3,527 \pm 868$ $\mathrm{mg}$ and $3,162 \pm 554 \mathrm{mg}$, respectively.

2) Significant correlation was observed only between sodium intake score and urinary sodium values $(r=0.389, p<0.05)$.

3) Differences in urinary sodium values according to the scores of each question were observed in the case of pickles, dried fish and heavy flavoring, but not in the case of soy bean soup, seasoning and instant noodle.

(Received April 11, 1985)

*1 T682 倉吉市福庭 854

*2 于803 北九州市小倉北区下到津 5-1-1

*3 个814 福岡市城南区別府 5-7-1

*4 T815 福岡市南区横手 1-456
*5 干816 福岡市博多区南八幡町 2-12-1

*6 个862 熊本市健單町字水洗 2432-1

*7 于890 鹿児島市鴨池町 1847 
近年ナトリウム摂取量に関する研究が多数みられる。 これらのなかには，尿中排泄量からの推定，陰膳方式に よる分析，いわゆる秤量法による計算値からの推定など の方法を検討したものが含まれており り ${ }^{1) ~ 3) ， ナ ト リ ウ ム ~}$ 摄取量把握の重要性と同時に，困難さをる示しているも のと思われる。

今回，われわれは対象者にとっては最も負担度の少な い質問法を用い, 塩分（ナトリウム）摂取についての食 習慣を調査し，その結果を並行して行なった他の三つの 方法によって得られた推定摂取量の值と比較した。塩分 摄取に関する質問調查は，すでに保健行政レベルで広く 行なわれているが，その結果に対し量的根拠に基ついた 評価はほとんどなされていない。るとより質問法で把握 される塩分（ナトリウム）拱取は，1日ないし3日間と いう短期間の食事の分析結果, あるいは計算によるナト リウム摄取量の推定値，または 1 日ないし数日のナトリ ウム尿中排泄量とは必ずしも一致しないはずである。し かし質問法による食習慣調查の結果を，量的に評価する ことはきわめて興味のある課題といえる。

$$
\text { 方法 }
$$

本調査は九州全域の中年夫婦を対象として予定された 健康指標探索のための地域調查の前に, 調査員自ら（な おこの対象者は全員栄盖士養成施設の教員であり, 秤量 法および陰㗏方式による調査精度は通常のフィールド調 查に比へて高いるのと思われる）が行なった食生活調査 で, 時期は昭和 56 年 6 月中旬である。本報に関する調查 内容は, 身長, 体重, 皮下脂肪厚, 血圧, 食習慣, 食品 摄取，およびナトリウム摄取についてである。

食習慣についてのアンヶート調査は, 食事のとり方に 関して 4 項目，塩分のとり方に関して 7 項目を設け，お のおの 3 段階評価で判定させた。な却設問の項目につい ては各種の食習慣調查内容45) およびライフプラニンク センターによる生活習慣尺度6)のらちの塩分に関する項 目を参考とした。回答は，「はい」「「をぎき」「いい え」の 3 段階より選択させ，これらの設問回答をると に, 低塩が低得点となるように $1 \sim 3$ 点に得点化し, そ の合計を塩分摄取得点とした。

食品摂取については, 連続 3 日間の食事を各食品ごと に自己秤量方式により記録し，32の食品群に分類，集計 して 3 日間の平均を求めた。

ナトリウム摂取については次の 3 万法により推定し た。(1)連続 3 日間の食事を陰眻方式によって採取し， 1 日ごとに全量をホモジナイズして乾式灰化後，炎光光度 法により测定し 3 日間の平均を求めた（以下，食事実測 值とよぶ)。(2)同し 3 日間の食事の自己秤量方式による 資料をるとに三訂補日本食品標準成分表 ${ }^{72}$ より計算し 3
日間の平均を求めた（以下，食事計算值とよら゙)。(3)同 し 3 日間の 24 時間尿中のナトリウム量を炎光光度法に より測定し， 3 日間の平均を求めた（以下，尿ナトリウ ム值とよぶ。このうち食事実測值と食事計算値につい ては, 同一の食事内容の結果である。尿ナトリウム值に ついては, 健康人の排泄量は多量の発汗や下浰がない状 態では摂取量とほぼ等しく，量としては $2 \sim 3$ 日前の摄 取量を反映したものと考えられている8)。したがって調 查実施時の摄取量とは異なる可能性がある。

\section{結果と考察}

\section{1. 対象の概況}

対象は健康な女子 33 名で，平均年龄は 48 墄であり， 肥満度, 血圧値とも正常域にある比較的等質的な集団で ある(表 1 )。

\section{2. 塩分のとりちについての回答}

表 2 に食習慣に関する設問のらち塩分のとり方につい ての回答結果を示す。また塩分摄取得点の度数分布を図 1 に示す。得点は 7 点から16点までに分布しており, 平 均 11.8 点である。

\section{3. 三つの測定法により推定されたナトリウム摄取量}

三つの方法によって, 食事実測值は $3,162 \pm 554 \mathrm{mg}$, 食事計算値は $3,806 \pm 753 \mathrm{mg}$, 尿ナトリウム値は 3,527 $\pm 868 \mathrm{mg}$ といら測定値が得られた。食事実測值に比へ て同一資料の計算值が多いのは, 福本 $5^{9}$, 高橋 $5^{10)}$, 萩原ら ${ }^{11}$ 抽よび菅原ら の報告と一致した結果である。

因 2 亿食事計算値之食事実測値の相関とその回帰直線 を示す。相関係数は $0.750(p<0.01)$ であり，菅原ら") の 0.378 (n.s.), 福本 $5^{9)}$ の 0.435 ( $p<0.01$, 三訂に よる 68 例の塩分量より筆者算出) といら数値に比べて かなり高い。これは通常の調査と異なり, 調査員自身が 自分の食事を秤量し，その陰膳を採取したことによるる のと思われる。

図 3 K食事計算値と尿ナトリウム值の相関とその回帰 直線を示す。相関係数は $0.503(p<0.01)$ で, 金子ら ${ }^{3)}$ の 0.369 ( $p<0.01, n=79$ て塩分量としての相関), 佐々木ら ${ }^{12)}$ の $0.658(p<0.05, n=10)$, 小林ら ${ }^{13)}$ の $0.54(p<0.01, n=39)$ 等と, 例数を考虑して比較す るとほぼ同程度で, いずれる高い相関とはいえない。

図 4 に尿ナトリウム值と食事実測値の相関とその回帰 直線を示す。相関係数は $0.490(p<0.01)$ であり，こ れる高い相関とはいえない。

以上，三つの方法によるナトリウム撕取量のなかで最 す高値を示した食事計算值については，他の文献のデー タにおいても，実測値よりも高いことが知られており， 測定誤差や調理に伴う消失などを理由に，計算値からの 撕取ナトリウム量の推定については，否定的な見解も示 
表 1. 調查対象の年龄, 体格, 皮下脂肪厚, 血圧

\begin{tabular}{|c|c|c|c|c|c|}
\hline 年 (歳) & ${ }^{(\mathrm{cm})^{\text {長 }}}$ & 体 ${ }_{(\mathrm{kg})}$ 重 & $\begin{array}{c}\text { 皮下脂肪厚 } \\
(\mathrm{mm})\end{array}$ & $\begin{array}{c}\text { 最高血王 } \\
(\mathrm{mm} \mathbf{H} \mathrm{g})\end{array}$ & $\begin{array}{c}\text { 最低血王 } \\
(\mathrm{mm} \mathrm{Hg})\end{array}$ \\
\hline $48.0 \pm 8.1$ & $155.1 \pm 4.4$ & $52.9 \pm 5.4$ & $37.3 \pm 9.7$ & $116.2 \pm 18.1$ & $73.7 \pm 10.9$ \\
\hline
\end{tabular}

$n=33$. 数値は平均土標準偏差

表 2．塩分のとり方に関連する質間に対する回答

\begin{tabular}{|c|c|c|c|}
\hline$\cdot$ & は い & ときどき & いいえ \\
\hline 漬物類をよく食べるか & $11(33.3)$ & $14(42.4)$ & $8(24.3)$ \\
\hline 塩干魚をよく食べるか & $0(0)$ & $10(30.3)$ & $23(69.7)$ \\
\hline 塩葴品をよく食べるか & $1(3.0)$ & $13(39.4)$ & $19(57.6)$ \\
\hline みそ汁をよく食べるか & $17(51.5)$ & $11(33.3)$ & $5(5.2)$ \\
\hline 料理にしょうゆ, ソース, 塩をよくかけるか & $6(18.2)$ & $15(45.4)$ & $12(36.4)$ \\
\hline インスタントラーメン類をよく食べるか & $0(0)$ & $3(9.1)$ & $30(90.9)$ \\
\hline 料理の味付は濃いものを好さか & $1(3.0)$ & $19(57.6)$ & $13(39.4)$ \\
\hline
\end{tabular}

回答基準は はい： 5 回/ 1 週間以上, ときどき：3 4 回/ 1 週間, いいえ：2 回/ 1 週間以下

( ):\%

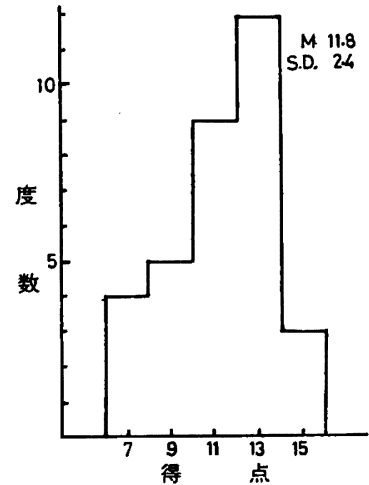

図 1. 塩分摂取得点の分布

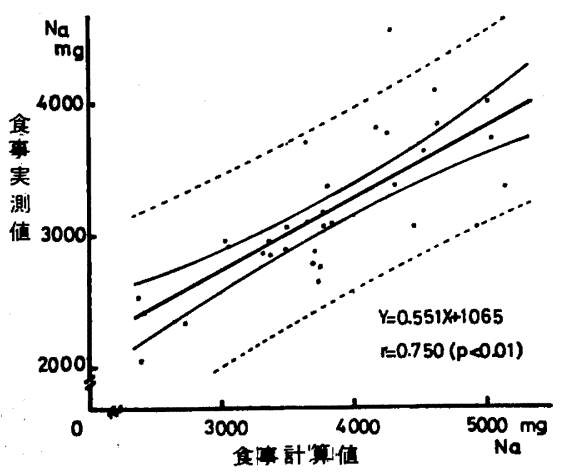

因 2. 食事計算値之食事実湘値の相関・回帰 回㷌直線とその $95 \%$ 信頼限界, 破線は $95 \%$ 信頼 区間を示す。

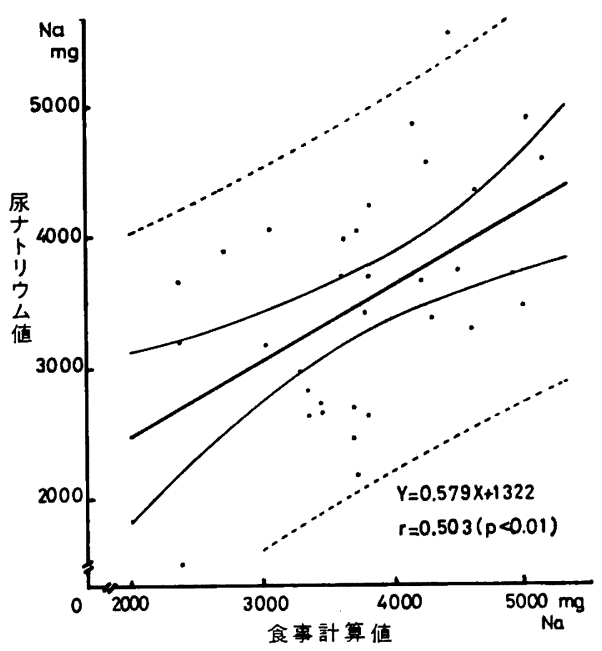

困 3. 食事計算値と尿ナトリウム値の相関・回帰 回帰直線とその $95 \%$ 信頼限界, 破線は $95 \%$ 信頼区 間を示す。

されている1》。一方，最も低値であった食事実測值につ いては, 測定前の収集, 計量, 処理の段階での誤差や消 失による影警す考えられるか，今回の分析から判断する ことはできない。結局，健康人を対象とした多量の発汗 のない時期の調查で，かつ 24 時間蓄尿が可能であると いら限定された条件のすとでは，尿中排泄量による推定 値を比較的精度の高い推定值とみなすことができるだろ 5 . 
表 3 ．塩分に関する設問得点別尿ナトリウム量

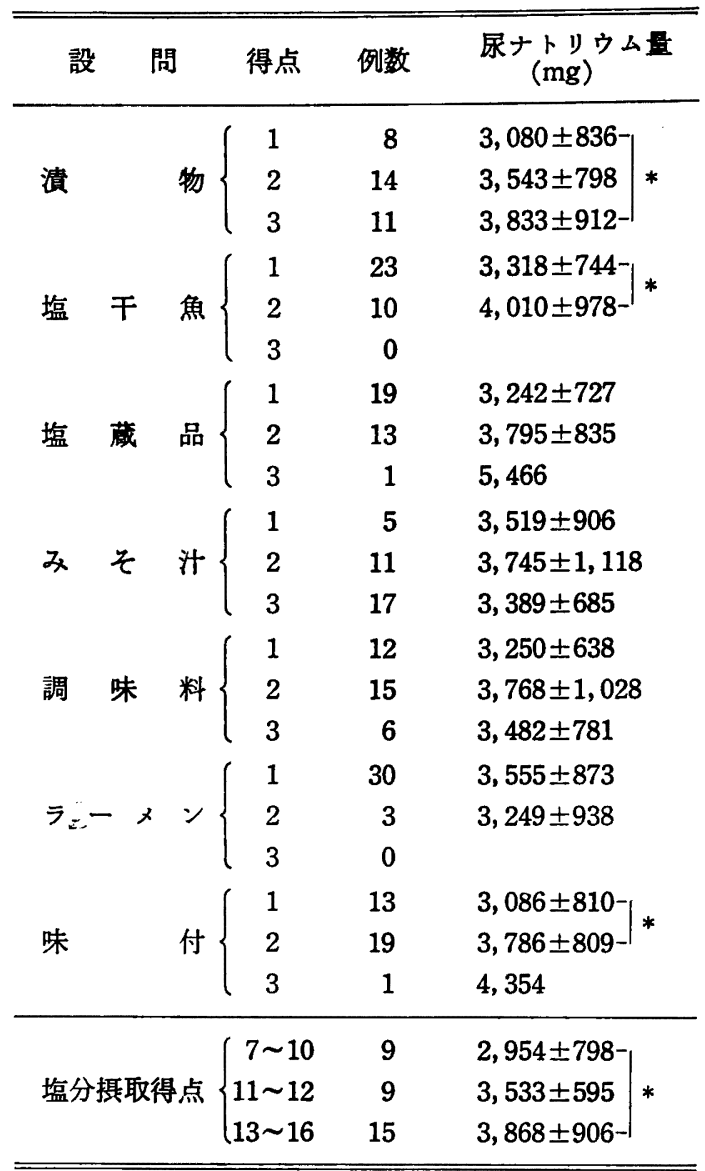

数値は平均土標準偏差

* $t$ 検定 : $p<0.05$.

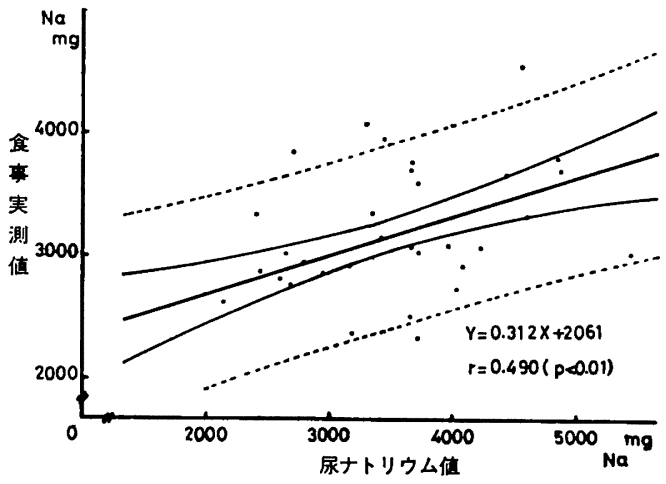

図 4. 尿ナトリウム值と食事実測値の相関 - 回帰 回帰直線とその 95\% 信頼限界, 破線は 95\% 信頼区 間を示す。

\section{4. 䣼問法と他の测定法の関連}

次に各設問に対する回答と，それらを統合した塩分撕

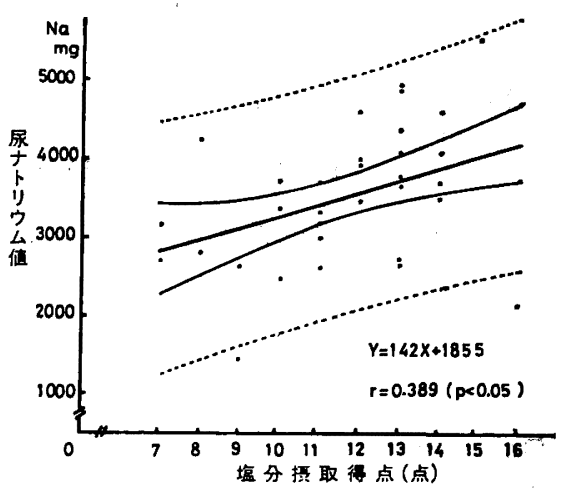

図 5. 塩分摄取得点と尿ナトリウム値の相関・回帰 回帰直線とその 95\% 信頼限界，破線は $95 \%$ 信頼区 間を示す。

取得点が三つの方法により得られたそれぞれのナトリウ ム摄取量ととのような関連があるかを検討した。

塩分摄取得点と各測定法によるナトリウム摄取是との 相関は，食事実測值との間で 0.172 , 食事計算値との間 で 0.288 と低く，尿ナトリウム值との間にのみ 0.389 と いうあまり高くはないが有意の相関がみられた。困5に 塩分摄取得点と尿ナトリウム值の相関とその回帰直線を 示す。しかしこの回帰直線とその $95 \%$ 信頼限界にす示 されるように，塩分拱取得点によるナトリウム撕取量の 直接的推定については, 精度の点で問題がある。これら の結果は, 離散量と連続量の関連をみるということで, 方法的にも困難を伴うことを示すと同時に，塩分㩒取得 点によって直接的に掑取量の推定を行ならことに無理が あることを示している。

表 3 に，塩分摄取にかかわる設問の得点別に尿ナトリ ウム量を示した。漬物，塩干魚，味付の程度については 得点による有意差が梕められた。みそ汁と調味料につい ては得点と尿ナトリウム量の間に対応が認められなかっ た。これらは広く用いられている項目であるが，食生活 の変化に伴い必ずしも塩分摄取状況の判断に有効な設問 とはいいがたいことを示している。みそ汁の設問につい ては食事のなかでの位置が変化していることをこの結果 は示唆している。なお調味料の設問については,できあ がった料理に付加する調味料についての設問 と理 解さ れ、これがナトリウム揁取量には直接影響を及ぽすよ5 な頻度と量ではないことを示している。またインスタン トラーメンについては得点別の例数のかたよりに示され るよらに摄食頻度, 年岭による嗜好差等が考えられ,むし ろめん類一般として検討するほうが妥当だったかるしれ ない。なお塩分撕取得点 7〜10 のものと, 13〜16 のる のについて尿ナトリウム者を比較すると，低得点群は $2,954 \pm 798 \mathrm{mg}$, 高得点群は $3,868 \pm 906 \mathrm{mg}$ となり, 有 
表 4. 㙁分撕取得点と食品群別提取量および尿ナト リウム最と食品群別摄取量の相関

\begin{tabular}{lcc}
\hline \hline 食品群 & $\begin{array}{c}\text { 㙁分䀸取得点 } \\
\text { との相 }\end{array}$ & $\begin{array}{c}\text { 尿ナトリウム } \\
\text { 量との相関 }\end{array}$ \\
\hline ハン類 & $-0.368^{*}$ & $-0.414^{*}$ \\
油脂類 & $-0.422^{* *}$ & -0.299 \\
魚加工品類 & $0.383^{*}$ & $0.427^{*}$ \\
肉 類 & -0.292 & -0.165 \\
渍物類 & 0.321 & $0.454^{* *}$ \\
\hline \hline
\end{tabular}

* $p<0.05,{ }^{* *} p<0.01$.

意の差がみられた。

\section{5. 垭分摄取得点と食品群別摄取量の関係}

塩分摄取得点と食品群別掫取量との関連を表 4 亿示し た。表 4 に用いた食品群別撕取量は种量による 3 日間の 平均で，そのらち比較的高い相関係数をすつるののみを とりあげて示してある。比較のために同時に尿ナトリウ ム量と食品群別摄取量との相関も示した。パン, 油脂類 （種実類を含む） 飞有意の負相関，魚加工品類に有意の 正相関が認められ塩分のとり方と食バターンとの間に関 連のあることを示している。

\section{要 約}

一般健康者を対象としたナトリウム摄取状況評価を前 提に，食習慣に関する質問に対する回答と，食事中およ び尿中のナトリウム量との関連を分析した。

1）食事中ナトリウム (実測値), 計算ナトリウム (計 算值)，尿ナトリウムの 3 日間の測定を行ない。食事実 测值 $(3,162 \pm 554 \mathrm{mg})<$ 尿ナトリウム值 $(3,527 \pm 868$ $\mathrm{mg})<$ 食事計算値 $(3,806 \pm 753 \mathrm{mg})$ の結果を得た。

2) 簡便に摄取ナトリウム量を把握したいと考兄て, 塩分摄取に関する設問に対する回答を得点化し，その合 計点を塩分摄取得点として表わした。塩分摂取得点は, 尿ナトリウム值とのみ有意の相関 $(r=0.389, p<$ 0.05)を示した。

3）個別の設問に対する回答をみると，漬物，塩干
魚, 味付については得点によって尿ナトリウム値に有意 の差が認められた。しかし, みそ计, 調味料, インスタ ントラーメンについては規則性が認められなかった。

終りに本研究をまとめるにあたり，ご指導，こ校閱い ただいた東京大学医学部保健学教室豊川裕之助教授に深 謝の意を表します。また食事中ナトリウム，尿ナトリウ ムの測定にご指尊，ご援助いただいた鹿児島大学医学部 付属病院中央検査部尾辻省悟教授ならびに日本医学研究 所実㴊 豊氏に深謝いたします。

なお本研究は九州実践栄養研究会資料によるすのであ り, 一部は第 36 回日本栄堆・食糧学会において発表し た。

\section{文献}

1) 菅原和夫, 熊江 隆, 町田和彦, 島岡 彰, 大下 喜子，鉿木継美 : 栄食誌，36，15 (1983)

2）竹森幸一，化平 将，三上聖治，神裕，佐々 木直亮：日本公衛誌，30,588 (1983)

3）金子佳代子, 小池五郎 : 栄食誌, 36, 43 (1983)

4) 厚生省公臬衛生局栄養課編: 昭和 57 年版国民栄 埗の現状, 26 (1982), 第一出版 (東京)

5）大和田国夫，伊達ちぐさ，田中平三，植田 豊, 津江裕子: 臨床栄美, 45, 343 (1974)

6) 日野原重明，柳井晴夫，高木廣文，柏木恵子，日 野原緑：日本公衛誌，29，309（1982）

7) 科学技術庁資源調查会編: 三訂補日本食品標準成 分表 (1980), 大蔵省印刷局（東京）

8) Talbot, N.B., Richie, R.H. and Crawford, J.D. : Metabolic Homeostasis (1959), Harvard University Press (Cambridge)

9）福本順子, 中島けい子：栄盖と食糧, 35,125 (1982)

10) 高橋リエ, 岩井初枝, 森 文平: 栄盖学雑誌, 42 , 167 (1984)

11）萩原清和, 津田明子, 渡辺智子, 神田紀子, 高畑 京二, 高居百合子, 岩尾裕之: 栄養学雑誌, 41, 313 (1983)

12）佐々木直亮，菊地亮也：食塩之栄養, 94 (1980), 第一出版 (東京)

13）小林真智子, 永原良美, 入部美則, 志賀美智子, 鏡森定信, 渡辺正男 : 栄盖学雅誌, 40, 259(1982)

（昭和 60 年 4 月 11 日受理） 